Rahmad Achri Subri : USG Pengganti Hukum Iddah Perspektif Maqashid Syari'ah.

DOI:10.24014/af.v18.i1.7045

USG Pengganti Hukum Iddah Perspektif Maqashid Syari’ah.

\author{
Rahmad Achri Subri \\ Ponpes al-Ihsan Boarding School Riau \\ rahmatsubri@gmail.com
}

\begin{abstract}
This study aims to find out and analyze the role of USG as well as to know and analyze legal determination ah iddah through USG in the perspective of Maqashid Syariah. This study is a library research (Library Research), in this study The type of data used in this study is a type of qualitative data. Based on the results of the author's research, it was concluded that the development of modern technology could not change the provisions of the short length of the Iddah period which had been determined and explained the Qur'an and Hadith. Although there is a belief that the divorced woman's womb is clean and between husband and wife it is impossible to reconcile. Thus, the problem of Iddah in Islamic teachings is ta'abbudi (devotion to Allah) and not ta'aqquli (cause and reason). At certain times when a woman who is divorced falls into the category of 'Iddah who has an irregular menstrual cycle and a monopouse woman, herein lies the role of USG in determining the length of iddah time's the woman is.
\end{abstract}

Keywords: Iddah, Maqashid Sharia, Islamic Law

\title{
Pendahuluan
}

Perkawinan merupakan ibadah yang termasuk paling lama jangka waktunya dari pada ibadah-ibadah lain bahkan sampai akhir hayatnya. Oleh karena itu, banyak ayat alqurandan hadits Nabi SAW yang menjelaskan tentang urgennya per kawinan dengan tujuan beribadah atau mendekatkan diri kepada-Nya. Dalam Kompilasi Hukum Islam Pasal 2 disebutkan bahwa perkawinan merupakan akad yang paling kuat atau mitsaqan ghalizan untukTme ntaati perintah Allah SWT dan melaksanakannya merupakan ibaibadah.(KHI, 2001).

Dari sisi bahasa,mitsaqan ghalizan mengandung isyarat keyakinan isteri, bahwa kebahagiaan bersama suami akan lebih besar dari pada kebahagiaan hidup dengan ibu bapak, dan pembelaan suami tidak lebih sedikit dari pada pembelaan saudara-saudara Kandung.(Khoiruddin, 2009).

Berkenaan dengan hal ini, Islam mengakui bahwa dalam hidup rumah tangga tidak selalu berjalan dengan baik sesuai dengan tujuan perkawinan. Tidak sedikit pasangan suami istri yang dalam perjalanan bahtera rumah tangganya putus di tengah jalan dengan berbagai sebab, di antaranya dengan adanya perkawinan, dipertemukan dua manusia yang berbeda, baik latar belakang keluarga, pendidikan maupun kepribadian masingmasing. Maka wajar bila ada konflik dan tidak bisa untuk diselesaikan serta keutuhan rumah tangga tidak bisa dipertahankan sehingga ikatan 
perkawinan keduanya terputus. Oleh karena itu, dengan putus perkawinan maka hubungan suami isteri manjadi terputus, yang dalam istilah figh disebut thalak atau perceraian sebagai jalan keluar terakhir dari sebuah rumah tangga.

Sejak terjadi perceraian ini dalam Islam mulai diatur adanya 'iddah atau masa tunggu bagi perempuan (isteri) karena perem puan yang memiliki rahim dan mengalami kehamilan, maka sangat logis kalau "iddah berlaku bagi perempuan. Sedangkan laki-laki tidak belaku masa "iddah. (Sodik, 2004). Karena laki-laki tidak mempunyai rahim sehingga tidak mungkin untuk mengalami kehamilan. Akan tetapi laki-laki juga harus memperhatikan "perasaan" perempuan yang telah ditalak dan mempunyai toleransi terhadap mantan istrinya.

'iddah bagi perempuan sudah diatur ditetapkan oleh hukum syara' karena di dalamnya terdapat hikmah dan banyak kemaslahatan. Hikmah adanya perceraian supaya ada kesempatan untuk berfikir lebih dalam tentang perkawinan, atau berfikir dua kali sebelum memutuskan untuk mencari pasangan hidup yang baru. (Sodik, 2004). Kemaslahatan yang dapat diambil dengan adanya 'iddah antara lain, untuk melindungi dan memelihara keturunan (nasab) dari percampuran dengan laki-laki lain yang akan dinikahinya. Sebab kesucian seorang perempuan selama masa 'iddah tanpa menikah dapat diketahui dari kebebasan dan kekosongan rahimnya dari adanya janin yang ada dalam rahimnya. (Nunung, 2009). Juga dalam masa 'iddah mengandung nilai ibadah bagi perempuan, yakni mentaati perintah
Allah SWT. (Sodik, 2004).

Tujuan dari Maqasid alSyari'ah adalah untuk kemaslahatan manusia. Kemaslahatan tersebut tidak bisa diketahui tanpa memahami terlebih dahulu kandungan dari maqasid al- syariah. Salah satu aspek yang penting dalam memahami syari'at khususnya yang terdapat dalam alquranadalah melalui bunyi lafadznya. Misalnya, yang berkenaan tentang 'iddah yang terdapat dalam alquransurat alBaqarah ayat 228 bahwa kata quru', lafadz ini digunakan untuk dua maksud dengan pemahaman yang sama. Oleh karena itu, dengan memahami lafadz tersebut, maka semua mujtahid tidak keluar dari konteks lafadz, mereka hanya berbeda dalam hal sejauh mana kedekatan ijtihadnya dengan lafadz. (Arif, 2012).

Kemaslahatan manusia termasuk pada isi atau kandungan dari maqasid alsyariah. Atau dalam arti lain bahwa seluruh ajaran yang tertuang dalam alquranmaupun sunnah menjadi dalil adanya maslahah. Al-syatibi mengatakan, syari'at itu bertujuan untuk kemaslahatan manusia, cepat ataupun lambat secara bersamaan dan ajaran ini pasti berasal dari tuhan, apakah itu membawa kemaslahatan ataupun sebaliknya membawa kemafsadatan. (Arif, 2012). Syariah juga merupakan hukum dasar yang ditetapkan oleh Allah SWT yang wajib diikuti oleh orang Islam berdasarkan iman yang berkaitan dengan akhlak, baik dalam hubungannya dengan Allah SWT dan sesama manusia maupun dengan alam sekitarnya.(Ramin, 2012).

Seiring dengan berkembang 
Rahmad Achri Subri : USG Pengganti Hukum Iddah Perspektif Maqashid Syari'ah.

nya ilmu pengetahuan dan teknologi, terutama dalam bidang kedokteran dan juga rekayasa genetika yang sangat mengagumkan. Dengan kecanggihan teknologi, seorang perempuan dapat diketahui apakah ia sedang hamil atau tidak. Salah satu diantaranya adalah USG (Ultrasonografi), dengan USG ini seorang perempuan bisa mengetahui bagaimana keadaan rahimnya dalam waktu singkat.

Perkembangan dan kecanggihan teknologi khususnya dibidang kedokteran yang dapat mendeteksi kehamilan dalam waktu singkat dengan hasil yang akurat tersebut tentu saja akan menimbulkan pertanyaan hukum terhadap 'iddah.

\section{PENGERTIAN 'IDDAH}

Perempuan yang bercerai dari suaminya, wajib menjalani masa 'iddah, yaitu masa dimana ia tidak boleh menikah dengan laki-laki lain.(Amir, 2011). Kata 'iddah diambil dari kata, al-'adad' atau bilangan, karna maknanya mengandung pengertian bilangan (Quru') dan bulan, menurut kebanyakan. (Zainudin, 2013). Menurut istilah, kata iddah adalah sebutan atau nama bagi suatu masa dimana seorang wanita menanti atau menangguhkan perkawinan setelah ia ditinggal mati oleh suaminya atau setelah diceraikan baik dengan menunggu kelahiran bayinya, atau berakhirnya beberapa Quru', atau berakhirnya beberapa bulan yang telah ditentukan.(Amir, 2011).

Dalam kamus Lisanul 'Arab menurut bahasa kata iddah berasal dari kata Al-'adad. Sedangkan kata al-'adad merupakan bentuk masdar dari kata kerja ya'uddu yang berarti menghitung. Kata al-'adad memiliki arti dan ukuran dari sesuatu yang dihitung dan jumlahnya. Adapun bentuk jama' dari kata al-adad adalah al-adad begitu pula bentuk jama' dari kata iddah adalah al-'idad. Dan dikatakan juga bahwa seorang perempuan telah beriddah karena kematian suaminya atau talak suami kepadanya. (Mandzur, $1386 \mathrm{H}$ )

Istri yang akan menjalani 'iddah ditinjau dari segi keadaan waktu berlangsungnya perceraian adalah sebagai berikut : (Amir, 2011).

1. Kematian suami, 'Iddah perempuan yang ditinggal mati suaminya, baik telah digauli atau belum. 'iddah nya adalah empat bulan sepuluh hari.

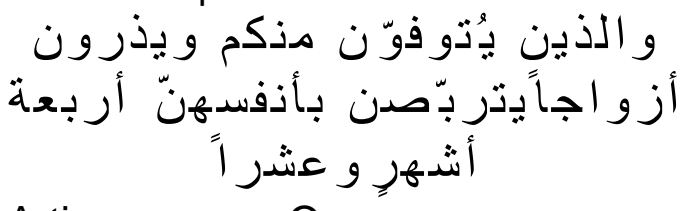

Artinya : Orang-orang yang meninggal dunia di antaramu dengan meninggalkan isteri-isteri (hendaklah Para isteri itu) menangguhkan dirinya (ber'iddah) empat bulan sepuluh hari.(Q.S. Albaqarah: 234).

2. Sudah dicampuri dan dalam keadaan hamil, 'iddah perempuan yang sedang hamil adalah melahirkan anak, sebagaimana firman Allah SWT: (Amir, 2011).

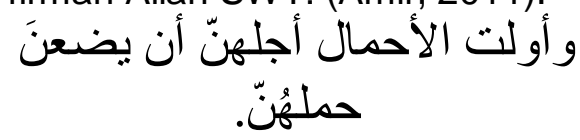

Artinya: dan perempuan-perempuan yang hamil, waktu iddah mereka itu ialah sampai mereka melahirkan kandungannya.(Q.S. At-Thalaq: 4).

3. Sudah dicampuri, tidak dalam keadaan hamil, dan masih dalam masa haid. Perempuan yang telah bergaul dengan suaminya dan masih menjalani masa haid 'iddah nya adalah tiga 
quru'.Adapun dasar hukumnya adalah firman Allah SWT:

و المطلقات بتربّصن بأنفسهنّ ثلاثنة قرو

Artinya: wanita-wanita yang ditalak handaklah menahan diri (menunggu) tiga kali quru'.tidak boleh mereka Menyembunyikan apa yang diciptakan Allah dalam rahimnya.(Q.S. Al-baqarah: 228).(Kemenag, 2012)

4. Sudah dicampuri, tidak dalam keadaan hamil, dan telah terhenti haidnya. Perempuan yang sudah digauli suaminya, tidak dalam keadaan hamil dan sudah terhenti masa haidnya, 'iddah nya adalah tiga bulan. Dasarnya adalah firman Allah surat Ath-Thalaq (65) ayat 4 :

و الّلآئي يئيسنْنَ من المحيض من نَّسأئكم

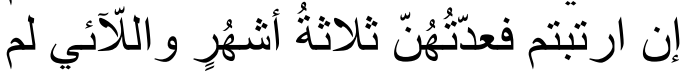

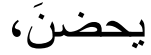

Artinya: dan perempuan-perempuan yang tidak haid lagi (monopause) di antara perempuan- perempuanmu jika kamu ragu-ragu (tentang masa iddahnya), Maka masa iddah mereka adalah tiga bulan; dan begitu (pula) perempuanperempuan yang tidak haid.(Q.S. Ath-thalaq:4).

5. Istri yang belum dicampuri

Syarat diwajibkannya'iddah yaitu istri sudah bergaul dengan suami.Bagi seorang wanita muslimah yang belum digauli suaminya, maka berdasarkan ijma' fuqoha' tidak mempunyai kewajiban menjalani masa iddah. Sesuai dengan firman Allah SWT.(Rusyd, 1990)

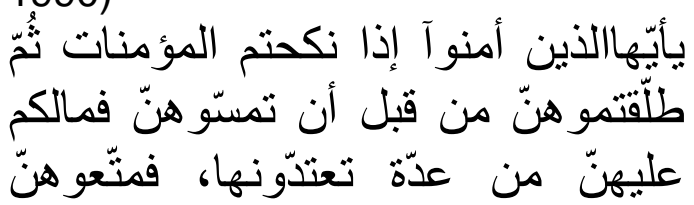

$$
\text { وسرّحو هنّ سر احاً جميلاً. }
$$

Artinya: Hai orang-orang yang beriman, apabila kamu menikahi perempuan- perempuan yang beriman, kemudian kamu ceraikan mereka sebelum kamu mencampurinya Maka sekali-sekali tidak wajib atas mereka iddah bagimu yang kamu minta menyempurnakannya. Maka berilah mereka mut'ah dan lepaskanlah mereka itu dengan cara yang sebaik- baiknya.(Q.S. Al-Ahzab: 49). Dan Rasulullah SAW juga bersabda

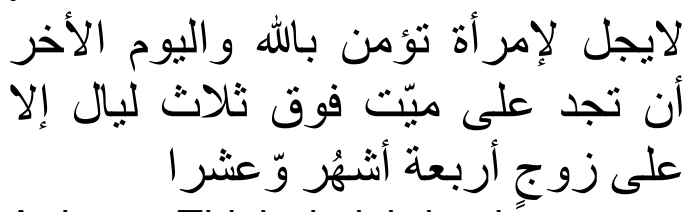
Artinya: Tidak halal bagi seorang perempuan yang beriman kepada Allah dan hari akhirat untuk berkabung terhadap kematian seseorang yang melebihi masa tiga hari, kecuali terhadap kematian suami yang berjalan selama empat bulan sepuluh hari. (Muslim, 1312 H)

\section{PENGERTIAN \\ ULTRASONOGRAFI DAN CARA KERJANYA}

Ultrasonografi sering disingkat USG, atau dalam bahasa inggrisnya Ultrasound adalah suatu alat untuk memeriksa organ dalam atau jaringan tubuh manusia dengan menggunakan gelombang bunyi berfrekuensi sangat tinggi. Cara Kerja Ultrasonografi melalui Gelombang USG dihasilkan oleh sebuah tranduser (alat transmisi dan penerima gelombang USG) yang mampu mengubah sinyal elektrik menjadi gelombang mekanis. Tranduser yang sama dapat pula menerima gelombang yang dipantulkan dan kemudian 
Rahmad Achri Subri : USG Pengganti Hukum Iddah Perspektif Maqashid Syari'ah.

DOI:10.24014/af.v18.i1.7045

mengubahnya kembali menjadi sinyal elektrik.(Palmer, 2001)

Getaran USG yang

dipantulkan dan terdeteksi lewat tranduser harus diperkuat atau diamplifikasi dalam skener. Echo yang kembali dari struktur yang lebih dalam tidak sekuat echo yang berasal dari jaringan yang berada di dekat permukaan, sehingga memerlukan amplifikasi yang lebih besar. Skener USG memiliki alat kontrol yang dapat mengubah keseluruhan sensitifitas, yaitu nilai ambang dari instrumen tersebut disamping mengubah amplifikasi echo dari pelbagai kedalaman yang berlainan. (Palmer, 2001)

Ketika echo kembali pada tranduser, gambaran dari semua jaringan yang sudah ada dalam berkas pancaran suara tersebut dapat direkonstruksi. Informasi tersebut disimpan dalam komputer dan diperhatikan melalui monitor video atau televisi. (Palmer, 2001)

\section{MANFAAT ULTRASONOGRAFI}

Ultrasonografi digunakan oleh dokter atau operatornya untuk:

1. Memastikan kehamilan

2. Mengenali kehamilan tunggal atau kembar

3. Memperkirakan usia kehamilan

4. Mengetahui posisi plasenta dan kondisinya

5. Ukuran cairan ketuban

6. Kelainan posisi janin

7. Jenis kelamin bayi

Dengan demikian, jika hasilnya menunjukkan hasil yang tidak normal, maka sang ibu dapat bertindak lebih cepat untuk menyelamatkan janin. Karena gangguan aliran darah pada janin dapat mengakibatkan pertumbuhan janin terhambat dan pada keadaan yang sudah berat dapat mengakibatkan kematian. (Palmer,
2001)

\section{TINGKAT KEAKURATAN YANG DIHASILKAN OLEH TEKNOLOGI USG}

Tidak seperti sinar- $X$, ultrasonografi dapat menunjukkan jaringan-jaringan lembut secara mendetail dan menghasilkan gambar janin yang sangat akurat dan terlihat seperti keadaan sebenarnya. Waktu dari pelaksanaan USG mempengaruhi keakuratan dari penentuan usia kehamilan. Semakin awal USG digunakan maka akan semakin baik. Jika USG digunakan tidak pada masa awal, maka akan sangat sulit untuk mengukur dan menentukan usia kehamilan karena perkembangan bayi dalam usia kehamilan yang sama bisa saja memiliki ukuran yang berbeda. Beberapa bayi memiliki ukuran yang lebih besar dari rata-rata. Hal ini juga bisa mengakibatkan perbedaan dalam pengukuran dan perkiraan usia bayi.(Winarni,USG (Ultrasonography) ;, dalam https://janewinarni.wordpress.com/u sgultrasonography/, diakses pada 6 Oktober 2018)

Kelebihan dari USG salah satunya adalah dapat mendeteksi adanya janin dalam rahim wanita pada usia kehamilan 5-7 minggu. Jadi, proses untuk mengetahui kehamilan atau tidak sangat cepat. Padahal dalam Alquran, masa yang diberikan Allah untuk 'iddah (untuk memastikan bersihnya rahim) adalah tiga bulan atau empat bulan sepuluh hari.

\section{PENGERTIAN MAQASID}

SYARI'AH

Maqasid Syari'ah berarti tujuan Allah dan Rasul-Nya dalam merumuskan hukum- hukum Islam. Tujuan itu dapat ditelusuri dalam 
ayat-ayat Alquran dan Sunnah Rasulullah sebagai alasan logis bagi rumusan suatu hukum yang berorientasi kepada kemaslahatan umat manusia.(Effendi, 2005)

Kata maqashid adalah jamak dari kata maqshad yang berarti adalah maksud dan tujuan. Kata Syariah yang sejatinya berarti hukum Allah, baik yang ditetapkan sendiri oleh Allah, maupun ditetapkan Nabi sebagai penjelasan atas hukum yang ditetapkan Allah atau dihasilkan oleh mujtahid berdasarkan apa yang ditetapkan Allah atau dijelaskan oleh Nabi. Karena yang dihubungkan kepada kata syari'at itu adalah kata "maksud", maka kata syari'ah berarti pembuat hukum atau syar'i, bukan hukum itu sendiri. Dengan demikian, kata maqashid al-syari'ah berarti apa yang dimaksud oleh Allah dalam menetapkan hukum, apa yang dituju Allah dalam menetapkan hukum atau apa yang ingin di capai oleh Allah dalam menetapkan suatu hukum.

Dalam kajian ilmu ushul fiqh ditemukan pula kata al-hikmah (bukan hikmah yang sudah menjadi bahasa Indonesia) yang diartikan المقصودة من تشريع الاحكام الغاية tujuan yang dimaksud Allah dalam penetapan suatu hukum). Dengan demikian, maqashid al-syari'ah itu mengandung arti yang sama dengan kata hikmah. (Amir, 2008)

\section{CARA DAN TUJUAN MENGETAHUI MAQASHID SYARI'AH}

Cara mengetahui maqashid syariah diantaranya adalah;

1. Penjelasan yang diberikan oleh Nabi, baik secara langsung atau tidak langsung. Untuk itu seluruh Hadis Nabi berkenaan dengan penjelasan ayat Alquran, harus ditelusuri untuk menemukan kalau ada penjelasan Nabi tentang Allah dalam ayat ini.

2. Melalui asbabun nuzul. Asbabun nuzul itu ditemukan dalam uraian mufasir yang merujuk kepada kejadian yang berlaku pada waktu turunya ayat. Kesuliannya adalah tidak semua ayat disebutkan asbabun nuzulnya dan ang disebutkan belum tentu disepakati para ulama'.

3. Melalui penjelasan ulama mujtahid atas penelitian atau pamahamannya terhadap firman Allah yang berkaitan dengan hukum.

4. Melalui kaidah kebahasaan yang menjelaskan tanda-tanda atau indikasi yang menjelaskan sebab dan akibat seperti yang dipahami dari tanda untuk ta'lil.(Amir, 2008)

Adapun tujuan mengetahui illat hukum antara lain;

a. Untuk dapat menetapkan hukum pada suatu kasus yang padanya terdapat illat hukum, namun belum ada hukum padanya dengan cara menyamakannya dengan kasus yang sama yang padanya terdapat pula illat hukum tersebut dalam arti yang sederhana untuk kepentingan qiyas. Inilah yang disetujui oleh mayoritas ulama' dan berlaku dalamillat yang punya daya jangkau atau illat muta'addiyah.

b. Untuk memantapkan diri dalam beramal. Berlaku pada illat yang tidak punya daya rentang/illat al- 
Rahmad Achri Subri : USG Pengganti Hukum Iddah Perspektif Maqashid Syari'ah.

DOI:10.24014/af.v18.i1.7045

qashirah. Seseorang akan mantap dalam melakukan perintah shalat waktu dia tahu bahwa shalat itu dzikir, sedangkan dzikir adalah menenangkan jiwa. Bentuk seperti ini diterima oleh para ulama.

c. Untuk menghindari hukum. Artinya menetapkan illat untuk suatu hukum dengan tujuan menetapkan hukum kebalikannya sewaktu illat itu tidak terdapat pada kasus tersebut. Umpamanya aurat perempuan adalah selain muka dan telapak tangan yang ditetapkan melalui hadis Nabi. Namun didalam hadis nabi tidak disebutkan alas an atau illatnya. Ada ulama yang mencari-cari illat-nya, yaitu "untuk membedakan perempuan merdeka dengan sahaya". Jika itu illat-nya tentu waktu ini yang sudah tidak ada perbudakan, maka tidak relevan lagi batas aurat yang disebutkan dalam hadis Nabi itu. Contoh lain; seseorang ulama kontemporer menetapkan waktu ini tidak perlu lagi melihat bulan untuk mengetahui awal puasa atau hari raya idul fitri, meskipun ada perintah yang lebih jelas oleh Nabi untuk melakukan rukyat. Alasan yang dikemukakan adalah umat pada waktu Nabi itu tidak mampu melakukan hisab, sedangkan sekarang keadaan itu tidak ada lagi. Tujuan mencari illat akalakalan seperti ini tampaknya belum berkenan di hati mayoritas ulama.(Amir, 2008)

\section{AL-MASHLAHAH SEBAGAI MAQASID SYARIAH}

Adapun yang menjadi tujuan dari Allah dalam menetapkan hukum itu adalah al- mashlahah atau maslahat yaitu untuk memberikan kemaslahatan kepada umat manusia dalam kehidupannya di dunia, maupun dalam persiapannya menghadapi kehidupan akhirat. Dengan demikian maqashid syari'ah itu adalah maslahah itu sendiri. Atau maqashid syari'ah adalah mashlahah. Maksud Allah untuk kemaslahatan atau untuk memashlahatkan umat itu dapat dilihat dalam firman Allah dalam Alquran surat Al-Anbiyaa' ayat 107 yang bunyinya;

$$
\text { وما أرسلناك إلا رحمة للّعالمين. }
$$

Artinya : Kami tidak mengutusmu ya Muhammad, kecuali untuk rahmat bagi seisi alam.

Yang dimaksud rahmat disini adalah maslahat itu sendiri., Almashlahah secara etimologi berarti suatu yang baik, dirasakan lezat, oleh karenanya menimbulkan kesenangan dan kepuasan serta diterima oleh akal yang sehat. Kamus besar Bahasa Indonesia mengartikan mashlahat itu dengan sesuatu yang mendatangkan kebaikan. Dalam memberikan definisi kepada kata maslahah itu terdapat rumusan yang berbeda. Semula Imam Ghazali mengartikan al-maslahat sebagai berikut :

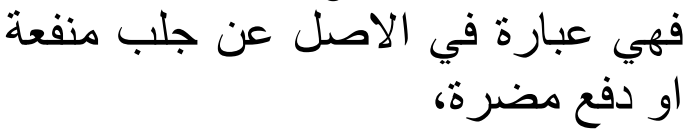

(menurut asalnya mendatangkan manfaat atau menolak جلب mudlarat). Atau secara ringkas (apa-apa yang منفعة او دفع مضرة 
mendatangkan manfaat atau menolak kemudlaratan). Arti yang sederhana itulah yang semula digunakan oleh Imam Ghazali. Namun karena "mendatangkan manfaat dan menghindarkan mudarat" itu merupakan maksud atas keinginan manusia, bukan maksud Allah, sedangkan mashlahat itu adalah maksud dari Allah yang membuat hukum, maka al-Ghazali membuat rumusan baru yaitu المحافظة على مقصودة الشرع (memelihara tujuan syara'), sedangkan tujuan syara' sehubungan dengan hambanya adalah menjaga agama, jiwa, akal, keturunan dan harta. Tujuan yang lima itulah yang popular dengan sebutan الاصول الخمسة (prinsip yang lima). Prinsip lima (الاصول الخمسة), diantaranya adalah

$$
\begin{aligned}
& \text { 1. Memelihara agama (حفظ (الاين) } \\
& 2 \text { Memelihara jiwa (حفظ الناس) } \\
& \text { 3. Memelihara Akal (حفظ العقل) } \\
& \text { 4. Memelihara Keturunan (حفظ }
\end{aligned}
$$

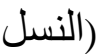

5. Memelihara Harta (حفظ المال)

Abu Ishaq al-Syatibi melaporkan hasil penelitian para ulama terhadap ayat-ayat Alquran dan Sunnah Rasulullah bahwa hukum-hukum disyariatkan Allah untuk mewujudkan kemaslahatan umat manusia, baik di dunia maupun di akhirat kelak. Kemaslahatan yang akan diwujudkan itu menurut al-Syatibi terbagi menjadi tiga tingkatan, yaitu kebutuhan dharuriyyah, kebutuhan hajiyat dan kebutuhan tahsiniyat.

1. Kebutuhan Dharuriyat (primer)

Kebutuhan dharuriyat ialah tingkat kebutuhan yang harus ada atas disebut dengan kebutuhan primer. (Effendi, 2005). Yakni sesuatu yang sangat perlu dipelihara atau diperhatikan seandainya tidak atau terabaikan membawa kepada tidak ada atau tidak berartinya kehidupan.(Amir, 2008). Bila tingkat kebutuhan itu tidak terpenuhi, akan terancam keselamatan umat manusia baik di dunia maupun akhirat.

2. Kebutuhan Hajiyat (sekunder) Kebutuhan hajiyat ialah kebutuhan-kebutuhan sekunder, dimana bilamana tidak terwujudkan tidak sampai mengancam keselamatannya, namun akan mengalami kesulitan. Artinya sesuatu kebutuhan untuk memeliharanya, jika tidak dipelihara tidak membawa pada hancurnya kehidupan, tetapi hanya menimbulkan kesulitan-kesulitan atau kekurangan dalam melaksanakannya.(Amir, 2008)

3. Kebutuhan Tahsiniyat (Tersier)

Kebutuhan tahsiniyat ialah tingkat kebutuhan yang apabila tidak terpenuhi tidak mengancam eksistensi salah satu dari lima pokok dan tidak menimbulkan kesulitan. Tingkat kebutuhan ini berupa kebutuhan pelengkap, seperti dikemukakan al-Syatibi, halhal yang merupakan kepatutan menurut adat istiadat, menghindarkan hal-hal yang tidak enak dipandang mata, dan berhias dengan keindahan yang sesuai dengan tuntutan norma dan akhlak.

\section{USG Pengganti Hukum 'Iddah Perspektif Maqashid Syariah}

Maqashid adalah sesuatu yang tersembunyi dalam diri yang bermaksud dan tidak dapat dilihat dari luar. Begitu pula maksud Allah SWT, terutama yang berkenaan dengan penetapan hukum adalah sesuatu yang tersembunyi. Oleh karena itu, hanya Allah yang 
Rahmad Achri Subri : USG Pengganti Hukum Iddah Perspektif Maqashid Syari'ah.

DOI:10.24014/af.v18.i1.7045

mengetahui maksud-Nya, yang mungkin dilakukan oleh manusia hanyalah "mengira" berdasarkan petunjuk yang ada, yang hasilnya bersifat relatif dan tidak sampai ke tingkat yakin atau dzanni.

Adapun yang menjadi tujuan dari Allah SWT dalam menetapkan hukum itu adalah al- mashlahah atau kemaslahatan yaitu untuk memberikan kemaslahatan kepada umat manusia dalam kehidupannya di dunia, maupun dalam persiapannya menghadapi kehidupan akhirat.Dengan demikian maqashid syari'ah itu adalah maslahah itu sendiri. Atau maqashid syari'ah adalah mashlahah. Maksud Allah untuk kemaslahatan atau untuk memashlahatkan umat itu dapat dilihat dalam firman Allah SWT yang bunyinya;

$$
\text { وما أرسلناك إلا رحمة للّحالمين. }
$$

Artinya : Kami tidak mengutusmu ya Muhammad, kecuali untuk rahmat bagi seisi alam.(Q.S. Al- Anbiya' :107)

Salah seorang pemikir muslim kontemporer, Jasser Auda, mengusulkan beberapa reformasi terhadap maqashid syariah dalam perspektif kontemporer. Pertama, keberanjakan dari maqashid syariah yang dulunya bernuansa protection (penjagaan) dan preservation (pelestarian) menuju maqashid yang bercita rasa development (pengembangan) dan pemuliaan Human Rights (hak-hak asasi manusia).

Kedua, Jasser Auda menawarkan tingkatan otoritas dalil dan sumber hukum Islam terkini, diantaranya hak-hak asasi manusia sebagai landasan dalam menyusun tipologi teori hukum Islam kontemporer. Terakhir, Jasser Auda mengusulkan reformasi sistem hukum Islam yang berbasis maqashid syariah. Inilah kontribusi signifikan yang diberikannya dalam rangka mereformasi filsafat hukum Islam melalui fungsi fitur-fitur sistem.(Auda, 2007)

Agar terbentuk keutuhan sistem berpikir, dalam memahami ketentuan Iddah dalam konsep maqashid syariah terutama dalam pandangan Jasser Auda, dibutuhkan enam fitur sistem yang dioptimalkannya sebagai pisau analisis. Sebagaimana penjelasan berikut;

1 Fitur Kognitif (cognitive nature of system/الإدركية (الإن )

Fitur kognitif merupakan fitur yang mengusulkan sistem hukum Islam yang memisahkan wahyu dari kognisinya. Itu artinya, fikih digeser dari klaim sebagai bidang pengetahuan ilahiah menuju bidang kognisi (pemahaman rasio) manusia terhadap pengetahuan ilahiah.(Auda, 2007)

Ketentuan Iddah, secara langsung diatur dalam sumber utama dan pertama hukum Islam, yaitu Alquran serta dikuatkan dengan sunnah sebagai sumber utama kedua. Berdasarkan fitur kognitif, maka ketika membahas doktrin Iddah adalah dengan langsung merujuk pada nash Alquran. Seperti firman Allah SWT : والمطلقات يتربّصن بأنفسهنّ ثناثةً

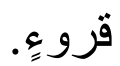

Artinya : wanita-wanita yang ditalak handaklah menahan diri (menunggu) tiga kali quru'.(Q.S. Al-baqarah: 228)

Ayat tersebut merupakan jumlah khabariah (terdiri dari mubtada dan khabar), يتربّصن Penggunaan istilah dengan bentuk khabariah untuk mengindikasikan perintah 
seperti ini, banyak digunakan dalam sistematika bahasa arab. Sehingga dari ayat tersebut dapat dipahami sebagai perintah Iddah bagi perempuan. Apalagi didukung dengan sunnah, Baik Alquran maupun sunah tidak menjelaskan ilat Iddah secara eksplisit. Bara'at al rahim atau kosongnya rahim istri adalah satu diantara beberapa ilat yang ditemukan, berdasarkan ijtihad ulama terdahulu dan juga diikuti oleh ulama kontemporer. llat tersebut masih pada tingkat kemungkinan bukan kepastian. Sehingga tidak bisa menafikan kewajiban Iddah yang telah mutlak. 2. Universal (wholeness/ الكلية)

Kemenyeluruhan yang dimaksud di sini adalah tidak hanya mengandalkan satu nash untuk menyelesaikan kasus tanpa memandang nash-nash lain yang terkait. Tapi lebih terbuka dengan seluruh ayat Alquran sebagai pertimbangan dalam memutuskan hukum Islam.

Dalam konsep Iddah, terdapat beberapa ayat yang menjelaskan ketentuan pelaksanaannya. Ketika dipahami secara menyeluruh ayatayat tersebut bukan semata menetapkan larangan yang seolah membatasi gerak perempuan. Tapi sebaliknya, sebagai jaminan penjagaan terhadap perempuan baik moril maupun materil dan penghormatan terhadap ikatan pernikahan yang mulia.

3 Keterbukaan (Openness/الإنفتاحية)

Fitur ini berfungsi untuk memperluas jangkauan 'urf (adat kebiasaan), yang menekankan pada pandangan dunia dan wawasan keilmuan seorang faqih, selain ruang, waktu dan wilayah yang dibangun atas basis ilmiah. Seperti membuka sistem hukum Islam terhadap kemajuan dalam-dalam ilmu alam, sosial dan budaya. Termasuk filsafat Mengenai doktrin Iddah bagi perempuan, sekiranya bisa dikaitkan dengan konteks perkembangan teknologi dan pranata sosial. Namun dalam menggunakan fitur ini, perlu pemahaman yang mendalam mengenai dasar wahyu kewajiban Iddah, agar tidak ada pelencengan makna yang dimaksud.(Bisri, 2004).

Dalam beberapa dalil tentang doktrin Iddah, tidak terdapat dalil yang menyatakan secara eksplisit tentang ilat diwajibkannya Iddah. Namun, kebanyakan ulama yang menyatakan kosongnya rahim adalah salah satu ilat kewajiban Iddah pasca putusnya perkawinan, di samping sebagai adab kesopanan dan ta'abbudi.

Hal ini membuktikan bahwa, kosongnya rahim bukanlah satusatunya ilat yang ada dibalik kewajiban lddah, sehingga kemajuan teknologi misalkan dengan adanya diagnosis kehamilan tidak akan menghapus kewajiban Iddah. Begitu juga dengan perubahan pranata sosial dalam kaitannya dengan peran perempuan.

\section{4 (Interelated/ mempengaruhi} saling yang Hierarki الهراكيرية المتتمة ) (تبديليا

Implikasi dari fitur ini adalah maqashid diderivasi dari seluruh bagian-bagian hukum Islam, sehingga menghasilkan khazanah maqashid yang lebih luas. Selain itu juga memperbaiki jangkauan orang yang diliputi maqashid dengan memberikan dimensi sosial dan publik. Sehingga maqashid menjangkau masyarakat, bangsa bahkan umat manusia.

Doktrin Iddah adalah salah 
Rahmad Achri Subri : USG Pengganti Hukum Iddah Perspektif Maqashid Syari'ah.

DOI:10.24014/af.v18.i1.7045

satu akibat hukum dari putusnya ikatan perkawinan sehingga menjadi bagian hukum di ranah hukum keluarga. Keluarga sebagai kom ponen terkecil dari masyarakat yang membentuk Negara. Kewajiban Iddah telah mutlak diatur dalam Alquran. Adapun bentuk pelaksa naan akan dipengaruhi kondisi sosial namun harus tetap menjaga eksistensi atau nilai ta"abbudi dan tujuan dari pensyariatan Iddah tersebut. Perbedaan tersebut terlihat dalam pelaksanaannya, seperti waktu penerapan larangan keluar rumah bagi wanita yang sedang menjalani masa Iddah dan bentuk larangan berhias yang juga dipengaruhi oleh keadaan setempat.

5 Multi Dimensionalitas (multidimensionality/تعدد ألأبعاد)

Diantara fitur yang bisa digunakan ketika menghadapi dilema dalil- dalil yang bertentangan, atau lebih tepatnya dalil-dalil yang seolah bertentangan adalah dengan cara memasukan dimensi maqashid. Implikasinya adalah hukum Islam menjadi lebih fleksibel dalam menghadapi problamatika kontemporer yang kompleks. Bahkan dalil-dalil yang selama ini tidak difungsikan, dapat difungsikan kembali melalui fitur multi dimensiaonalitas ini, dengan catatan dapat meraih maqashid Dalam konsep Iddah, penerapan fitur ini sangat berkaitan dengan fitur selanjutnya, yaitu kebermaksudan.

6 Tujuan (purposefulness / المقاصد)

Sistem pencarian tujuan (goalseeking systems) secara mekanis mencapai tujuan akhirnya dengan mengikuti cara-cara yang sama, pada lingkungan yang sama dan tidak memiliki kesempatan untuk mengubah cara-caranya untuk meraih tujuan yang sama. Di pihak lain, sistem pencari maksud (purpose-seeking systems) dapat mengikuti berbagai cara untuk meraih tujuan akhir atau maksud yang sama.(Auda, 2007)

Dalam memahami doktrin Iddah, kita bisa mengandalkan pemahaman ilat serta hikmah dari pensyariatannya.ASehinggaApelaks anaannya bisa relevan dengan perubahan sosial dan tetap mem pertahankan eksistensi pensyariat annya atau kebermaksudan hukum iddah. Kebermaksudan ini merupakan fitur yang menjangkau semua fitur yang dijelaskan sebelumnya dan mempresentasikan inti metodologi analisis sistem tersebut. Keenam fitur ini saling erat berkaitan, saling menembus (semipermeable) dan berhubungan satu sama lainnya.

Fitur kebermaksudan ini ditujukan pada sumber-sumber primer yaitu Alquran dan hadis. Dalam hal Iddah, baik Alquran dan sunah tidak menjelaskan ilat secara eksplisit. Ayat- ayat Alquran yang menjelaskan asas-asas pernikahan dapat membantu dalam memahami tujuan di balik ketetapan Iddah.

Dari keenam fitur tersebut, dapat disimpulkan bahwa Iddah memiliki status yang jelas dan pasti. Dalam memahami konsep Iddah tidak cukup hanya dengan menggali ayat atau hadis yang membahas Iddah secara khusus, tetapi juga ayat-ayat lain yang mendukung eksistansi Iddah, terutama ayat-ayat yang membahas perkawinan. Pelaksanaan Iddah bisa lebih terbuka terhadap perubahan sosial tapi dengan syarat tidak kehilangan substansi ta'abbudi dan kesopanannya.

Tidak hanya maqashid syariah, bahkan Alquran juga mengatur 
tujuan dan substansi dalam pernikahan dan perceraian, Pasal 3 $\mathrm{KHI}$ menjelaskan bahwa perkawinan bertujuan untuk mewujudkan rumah tangga yang sakinah, mawaddah dan rahmah, sebagaimana firman Allah :

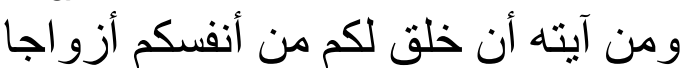

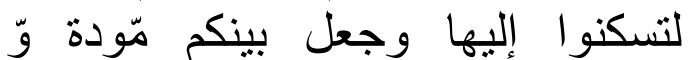
رحمة، إن في ذلك لأبات لقوم يتفكّرون. Artinya : dan di antara tanda-tanda kekuasaan-Nya ialah Dia menciptakan untukmu isteri-isteri dari jenismu sendiri, supaya kamu cenderung dan merasa tenteram kepadanya, dan dijadikan-Nya diantaramu rasa kasih dan sayang. Sesungguhnya pada yang demikian itu benar-benar terdapat tanda-tanda bagi kaum yang berfikir. ( Q.S. Ar- rum :21)

Salah satu hikmah ditetapkannya iddah adalah untuk mengetahui kebersihan rahim,semen tara hanya perempuan yang me miliki rahim dan mengalami keha milan, maka sangat logis jika iddah hanya berlaku bagi perempuan. Berarti dalam hal ini iddah hanya berhubungan dengan seks (jenis kelamin) dan bersifat kodrati dan tidak bisa dirubah hal ini bisa dibuktikan dengan tidak adanya literatur yang mengatakan bahwa ada masa Iddah untuk seorang lakilaki. Namun ada tujuan lain Iddah yaitu memberi kesempatan bagi masing-masing pasangan untuk rekonsisliasi, serta bertujuan untuk berkabung bagi istri yang ditinggal suami.(Coulson, 1964)

Dengan adanya perkembangan teknologi USG, kelompok tekstualis mulai menolak keberadaan 'illat hukum dari ketentuan Iddah. Sebagai argumen pengganti, dihadirkan teori lain yang mengatakan bahwa alasan utama Iddah bukan untuk mengetahui keadaan rahim, melainkan lebih karena tuntutan teks ajaran agama. Menurut mereka, meminjam bahasa ushul fikih Iddah disyariatkan tidak mengandung 'illat apapun. Dengan mengikuti kategorisasi hukum dalam ushul fikih Iddah termasuk ke dalam hukum ghair Ma'qulat al-Ma'na, sebuah ketentuan hukum yang harus diimani dan dilaksanakan oleh mukallaf tanpa perlu mempertanyakan apalagi menggugatnya. (Khallaf, 1956)

Keadilan yang dibawa Islam juga bisa dirasakan oleh perempuan yang bercerai dan pisah dari suaminya di dalam masa Iddah tidak seperti habis manis sepah dibuang. Perempuan yang diceraikan masih berhak atas nafkah dan tempat tinggal, serta tidak boleh disakiti secara fisik maupun psikis.

Dalam surat At-Thalaq ayat 4 Allah menetapkan hukum Iddah bagi perempuan yang belum menstruasi dan yang telah putus menstruasi yaitu selama tiga bulan. Para ulama berbeda pendapat dalam menentukan Iddah bagi perempuan hamil yang ditinggal mati suaminya. Ada yang menyatakan setelah melahirkan dan ada yang menambahi empat bulan sepuluh hari pasca melahirkan, Sebagai lambang solidaritas kekeluargaan. Al-Razi lebih condong pada pendapat yang pertama (setelah melahirkan).

Di samping itu pilihan tersebut memang paling rasional dengan beberapa argumen yang bisa dibangun: pertama, dalam AlQuran telah jelas diterangkan tujuan dari Iddah yang utama untuk mengetahui kebersihan rahim, bila sudah melahirkan jelas rahim 
Rahmad Achri Subri : USG Pengganti Hukum Iddah Perspektif Maqashid Syari'ah.

perempuan telah bersih dari adanya janin. Kedua,, Hikmah dibatasi Iddah isteri yang kematian suami 4 bulan 10 hari itu dikembalikan pada tujuan pokok iddah,yaitu "bara'atu rahim" (kebersihan rahim), sedangkan janin itu terbentuk di dalam rahim dalam tiga fase: Fase pertama, berbentuh nuthfah (air mani) selam 40 hari, fase kedua berbentuk darah menggumpal selam 40 hari, fase ketiga berbentuk daging selama 40 hari jadi seluruhnya berjumlah 120 hari (4 bulan). Sesudah masa itu barulah ditiupkan ruh kedalamnya, karena itu ditambah lagi dengan 10 hari. Abu Aliyah pernah ditanya : mengapakah 10 hari itu digabung dengan 4 bulan ? ia menjawab: karena di saat itulah ruh ditiupkan.(Arsal, 2007). Ketiga, hamil dan melahirkan adalah masamasa yang sulit bagi seorang perempuan, terlebih bila tidak ada pendamping disisinya. Bila penderitaan itu harus ditambah empat bulan sepuluh hari akan menjadi beban berat bagi perempuan. Keempat, mengasuh dan membesarkan anak merupakan tugas yang tidak ringan bila harus dipikul sendiri, maka wajar kalau perempuuan membutuhkan pendamping untuk memikul tanggungjawab tersebut.

Ayat-ayat Al-Qur"an mengenai Iddah dalam Al-Qur"an menurut versi kesarjanaan Islam maupun Barat- termasuk ayat-ayat yang diturunkan dalam periode Madinah atau pasca hijrah.(Amal, 2005). Dengan demikian konteks historis yang melatar belakangi ketentuan Iddah terjadi di dalam masyarakat Arab, khususnya Mekkah dan Madinah sesudah Hijrah.

Bagi perempuan yang terang- terangan berada dalam keadaan hamil sewaktu dicerai suaminya, perhitungan masa 'iddah nya adalah dengan kelahiran bayi yang dikandungnya. Hal ini mengisyaratkan bahwa kemurnian suatu bibit tidak hanya menyangkut materi bibit yang tumbuh, tetapi juga berkaitan dengan proses pemeliharaan dan pertumbuhannya. Secara medis, seorang perempuan yang digauli oleh beberapa orang laki-laki dapat mengetahui secara pasti pemilik bibit yang sedang dikandungnya. Namun dari segi lain, seperti pendidikan dan psikologi, akan terjadi kerusakan dan kekacauan moral di tengah-tengah masyarakat.(Sindo, 1996).

Salah satu hikmah Iddah dalam talak raj'i adalah memberi kesempatan kepada suami istri yang berpisah untuk kembali kepada kehidupan semula, jika mereka menganggap hal tersebut baik. (Sabiq, 1978). Iddah khususnya dalam talak raji merupakan tenggang waktu yang memungkinkan suami istri yang telah bercerai untuk berpikir dan merenung tentang hubungan mereka. Dalam masa ini, kedua belah pihak dapat saling intropeksi diri guna mengambil langkahlangkah yang diperlukan untuk menciptakan hubungan yang lebih baik. Terutama bila mereka mempunyai anak yang membutuhkan kasih sayang dan pendidikan yang baik dari orang tuanya.

Al-quran surat An-nisa' (4) ayat 35 mengisyaratkan agar pasangan suami istri yang sudah terlanjur berselisih paham sehingga mengancam keutuhan rumah tangga mereka supaya berusaha rujuk kembali, karena dari sudut 
manapun, pada dasarnya perbuatan rujuk itu adalah yang terbaik. Bahkan Al-Qur"an memberikan petunjuk agar jangan sampai terjadi talak. Allah berfirman :

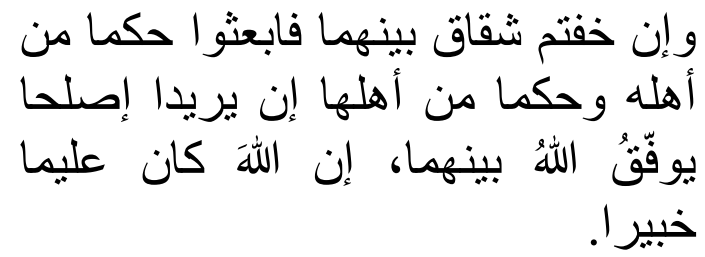

Artinya : dan jika kamu khawatirkan ada persengketaan antara keduanya, Maka kirimlah seorang hakam dari keluarga lakilaki dan seorang hakam dari keluarga perempuan. jika kedua orang hakam itu bermaksud Mengadakan perbaikan, niscaya Allah memberi taufik kepada suamiisteri itu. Sesungguhnya Allah Maha mengetahui lagi Maha Mengenal (Q.S. Annisa: 35).

Hal ini menunjukkan bahwa Islam tidak menginginkan terjadinya perceraian, karena keberadaan hakam bagi masing-masing pihak dipahami sebagai upaya agar tidak terjadi perceraian. Iddah wafat dimaksudkan untuk mengingat kenikmatan dan kebahagiaan ketika bersama dalam perkawinan. Disamping itu, juga untuk menghargai suami dan memelihara hak- haknya dan perasaan kerabatnya.

Kebaikan pernikahan tidak dapat terwujud sebelum kedua suami istri sama- sama hidup lama dalam ikatan akadnya. Iddah wafat dimaksudkan untuk mengingat kenikmatan dan kebahagiaan ketika bersama dalam perkawinan. Disamping itu, juga untuk menghargai suami dan memelihara hak-haknya dan perasaan kerabatnya. Bagi wanita yang dicerai sedangkan ia dalam keadaan hamil, Iddahnya adalah sampai ia melahirkan bayi yang dikandungnya.

Ketentuan Al-Quran tentang Iddah ini adalah suatu ketentuan yang mutlak harus diikuti, karena inilah syariat yang diturunkan kepada manusia untuk kemaslahatan mereka di dunia dan keselamatan mereka di akhirat kelak. Ketentuan- Nya ini tentu saja tidak dapat diubah.

Seiring dengan perjalanan waktu dan perkembangan peradaban manusia, ditambah lagi dengan kemajuan sains dan teknologi, perubahan-perubahan terus berjalan. Sesuatu yang tadinya dianggap mustahil oleh manusia, saat ini terjadi. Sesuatu yang sebelumnya tak terbayangkan adanya kini dapat disaksikan.

Berdasarkan uraian diatas, bahwa perkembangan ilmu teknologi modern tidak dapat mengubah ketentuan panjang pendeknya masa Iddah yang telah ditetapkan serta dijelaskan Alquran dan Hadis. Meskipun ada keyakinan bahwa rahim wanita yang dicerai itu bersih dan diantara suami-istri tidak mungkin rujuk kembali. Dengan demikian, masalah Iddah dalam ajaran islam ini adalah bersifat ta'abbudi (pengabdian diri kepada Allah) dan bukan bersifat ta"aqquli (sebab dan alasan).

Agama Islam meletakkan keluarga sebagai sesuatu yang tinggi dan mulia, terutama bagi pasangan suami isteri. Agama Islam sangat membenci perceraian dan keruntuhan mahligai rumah tangga. Makanya diberi kesempatan untuk mencegahnya.

\section{KESIMPULAN}

1. Stadium paling dini ketika suatu kehamilan dapat dikenali dengan pemeriksaan USG yaitu 
Rahmad Achri Subri : USG Pengganti Hukum Iddah Perspektif Maqashid Syari'ah.

pada kehamilan lima minggu. Lokasi kantong kehamilan merupakan bukti pertama terjadinya kehamilan. Kantong kehamilan sering dapat dikenali dalam uterus setelah lima minggu terjadi amenore. Semua kehamilan harus dapat dikenali setelah enam minggu. Dengan peranan alat ini, dapat mengetahui kondisi rahim karena alat yang digunakan dalam pemeriksaan Ultrasonografi (USG) ini ada tiga jenis (transducer, monitor, dan mesin USG). Tiga jenis alat tersebut saling berhubungan satu sama lain. Ketika salah satu alat yang disebut dengan transducer ini ditempelkan di sekitar perut ibu hamil maka dia akan memberikan gambaran berupa gelombang suara ultrasonik terhadap isi perut (rahim) yang kemudian akan dikirim melalui kabel ke dalam mesin USG. Mesin USG tersebut akan memproses gelombang suara ultrasonik dari apa yang dihasilkan oleh transducer, gelombang suara ultrasonik tersebut didalam mesin USG akan diproses.

2. Perkembangan ilmu teknologi modern tidak dapat mengubah ketentuan panjang pendeknya masa 'iddah yang telah ditetapkan serta dijelaskan Alquran dan Hadits. Meskipun ada keyakinan bahwa rahim wanita yang dicerai itu bersih dan diantara suami-istri tidak mungkin rujuk kembali. Dengan demikian, masalah 'iddah dalam ajaran islam ini adalah bersifat ta'abbudi (pengabdian diri kepada Allah) dan bukan bersifat ta'aqquli (sebab dan alasan) . Pada saat-saat tertentu ketika seorang wanita yang ditalak masuk kedalam kategori 'iddah wanita yang siklus haidhnya tidak teratur dan wanita monopouse maka disnilah letak salah satu peranan USG dalam menentukan lama 'iddahnya wanita tersebut

\section{DAFTAR PUSTAKA}

Amir Syarifuddin, Hukum

Perkawinan Islam Di Indonesia, (Jakarta: Kencana, 2011)

Auda, Jasser, Maqashid AI Sharia as Philosopy of Islamic Law, A Systems Approach, (London: IIUT, 2007)

Cik Hasan Bisri, Penuntun Penyusunan Pencana Penelitian dan Penulisan Skripsi Bidang IImu Agama Islam. (Jakarta: RajaGrafindo Persada. 2001)

Direktorat Pembinaan Peradilan Agama Islam, Kompilasi Hukum Islam, (Ditjen Pembinaan Kelembagaan Islam Departemen Agama, 2001)

Ibnu Rusyd, Terjemah Bidayatul Mujtahid, Jilid II, (Semarang: As-Syifa',1990)

JaneWinarni,USG(Ultrasonography) ,dalamhttps://janewinarni.word press.com/usgultrasono

graphy/, diakses pada 6 Oktober 2018

Juhaya S Praja, Tafsir Hikmah, (Bandung: Remaja Rosdakarya, 2000) Kemenag RI, Al-Quran dan

Terjemahannya, (Surabaya: Duta Surya, 2012)

$\begin{array}{rrr}\text { Khoiruddin } & \text { Nasution, Hukum } \\ \text { perdata } & \text { (Keluarga) Islam } \\ \text { Indonesia dan Perbandingan }\end{array}$ 
Al-Fikra: Jurnal IImiah Keislaman, Vol. 18, No. 1, Januari - Juni, 2019 (12-27)

DOI:10.24014/af.v18.i1.7045

Hukum Perkawinan di Dunia Muslim, (Yogyakarta: Academia, 2009), Cet. 1

Muhammad Sodik (Ed), Telaah Ulang Wacana Seksualitas, PSW IAIN Sunan Kalijaga, (Depag RI dan Mc Gill-IISEPCIDA, 2004)

Muslim, Al-Jami'us Shahih, jilid II, juz IV, (Beirut: Dar al-Fikr, tt)

P.E.S. Palmer (ed.), Panduan Pemeriksaan Diagnostik USG, Penerjemah: Andry Hartono, (Jakarta: EGC, 2001)

Quraish Shihab, Tafsir Al-Mishbah, Pesan, Kesan, dan Keserasian Alquran, (Jakarta: Lentera Hati, 2000)

Rahmat Syafe'i, IImu Ushul Fiqh, (Bandung: Pustaka Setia, 2010)

Rianta Adi, Metodologi Penelitian Social dan Hukum, (Jakarta: Granit, 2004) Sutrisno Hadi, Metode Research, (Yogyakarta: Andi Offset, 1990)

Umi Chaidaroh, Konsep 'Iddah Dalam Hukum Fiqh, (Surabaya: IAIN SA Press, 2013)

Wahbah Zuhaili, Fiqhul Islam Wa Adillatuhu, jilid IX, (Jakarta: Gema Insani, 2007)

Wahbah Zuhaili, Fiqhul Islam Wa Adillatuhu, jilid IX, (Jakarta: Gema Insani, 2007) 